
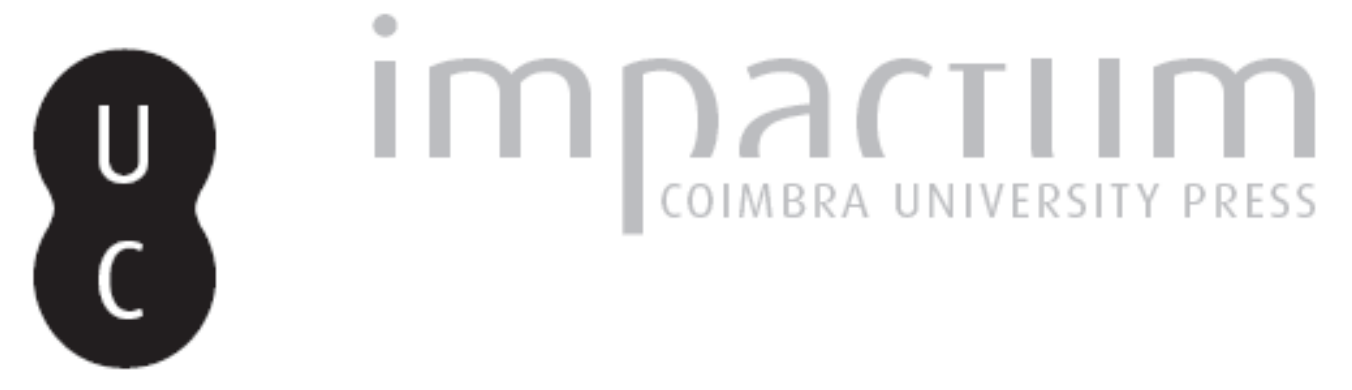

The reception of classical Latin literature in early modern philosophy: the case of Ovid and Spinoza

\author{
Autor(es): $\quad$ Pugliese, Nastassja \\ Publicado por: Imprensa da Universidade de Coimbra; Annablume \\ URL \\ persistente: \\ URI:http://hdl.handle.net/10316.2/44811 \\ DOI: \\ DOI:https://doi.org/10.14195/1984-249X_25_2 \\ Accessed : $\quad$ 26-Apr-2023 08:50:13
}

A navegação consulta e descarregamento dos títulos inseridos nas Bibliotecas Digitais UC Digitalis, UC Pombalina e UC Impactum, pressupõem a aceitação plena e sem reservas dos Termos e Condições de Uso destas Bibliotecas Digitais, disponíveis em https://digitalis.uc.pt/pt-pt/termos.

Conforme exposto nos referidos Termos e Condições de Uso, o descarregamento de títulos de acesso restrito requer uma licença válida de autorização devendo o utilizador aceder ao(s) documento(s) a partir de um endereço de IP da instituição detentora da supramencionada licença.

Ao utilizador é apenas permitido o descarregamento para uso pessoal, pelo que o emprego do(s) título(s) descarregado(s) para outro fim, designadamente comercial, carece de autorização do respetivo autor ou editor da obra.

Na medida em que todas as obras da UC Digitalis se encontram protegidas pelo Código do Direito de Autor e Direitos Conexos e demais legislação aplicável, toda a cópia, parcial ou total, deste documento, nos casos em que é legalmente admitida, deverá conter ou fazer-se acompanhar por este aviso.

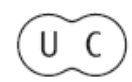




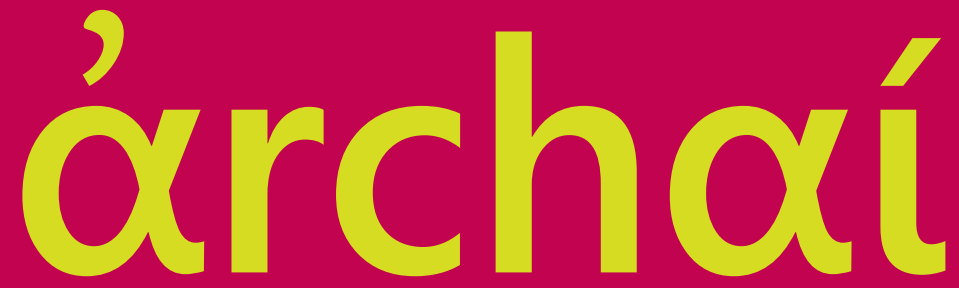

AS ORIGENS DO PENSAMENTO OCIDENTAL

THE ORIGINS OF WESTERN THOUGHT 


\title{
ảrchaí
}

AS ORIGENS DO PENSAMENTO OCIDENTAL

THE ORIGINS OF WESTERN THOUGHT

ARTIGO ORIGINAL I ORIGINAL ARTICLE

\section{The Reception of Classical Latin Literature in Early Modern Philosophy: the case of Ovid and Spinoza}

\author{
Nastassja Pugliese ${ }^{\mathrm{i}}$ \\ http://orcid.org/0000-0002-1961-3873 \\ nastassjapugliese@ufrj.br
}

\begin{abstract}
${ }^{\text {i }}$ Universidade Federal do Rio de Janeiro - Rio de Janeiro - RJ - Brasil
PUGLIESE, N. (2019). The Reception of Classical Latin Literature in Early Modern Philosophy: the case of Ovid and Spinoza. Archai 25, e02502.
\end{abstract}

Abstract: Although the works of the authors of the Golden Age of Latin Literature play an important formative role for Early Modern philosophers, their influence in Early Modern thought is, nowadays, rarely studied. Trying to bring this topic to light once again and 
following the seminal works of Kajanto (1979), Proietti (1985) and Akkerman (1985), I will target Spinoza's Latin sources in order to analyze their place in his philosophy. On those grounds, I will offer an overview of the problems of the reception of classical literature in Early Modernity and then dwell on the particular case of Ovid and Spinoza. The present paper will argue that although Spinoza's references to Ovid fill a rhetorical purpose as suggested by the existing literature, these mentions have a prior philosophical motivation. That is, the references in the Ethics are not merely illustrative; instead, they indicate that Spinoza acknowledges Ovid's beliefs about human experiences and deliberately elaborates on Ovid's view to construct and defend his own theses. To this end, the paper will analyze some citations mapped by Proietti (1985) and add a new one in an attempt to enlarge the list of places and topics that merit further investigation. To conclude, I will point out how the references to Ovid are part of Spinoza's own defense of the powers of imagination.

Keywords: Ovid, Spinoza, Reception of Latin Literature.

\section{The Reception of Classical Latin Literature in Early Modernity}

Early Modernity, considered as the tail end of Renaissance Humanism, marks the end of the literae humaniores. Studies on the emergence of modernity (e.g. Popkin, 1996, Boas, 1957, Koyrè, 1957) show that, during this time, the focus of philosophical investigation shifts from the classical letters to the sciences. The contrast between these two periods, Renaissance Humanism and Early Modernity, contribute to the misconception that modernity is marked by a widespread rejection of the classics and tradition. But in a closer examination, we see that the reception of classical Latin literature by Early Modern philosophers is multifarious. If, on the one hand, the Classical Latin canon was starting to lose their previously unwavering influence due to the reaction against tradition, on the 
other hand, the classical authors were still sources of philosophical discussions and the model of rhetoric for Early Modern philosophers. ${ }^{1}$ Philosophers that represent the transition of periods exhibit very different relationships with the classics. Take, for instance, the works of Montaigne and Descartes. As good examples of Early Modern philosophers, they both reacted against tradition: Montaigne expressing skepticism towards rational knowledge, and Descartes formulating a method that is grounded in doubting every traditional belief. Their works, however, display two different approaches to the classical letters, constituting two opposing extremes: while a significant part of Montaigne's Apology of Raymond Sebond are references to Roman authors, Descartes avoided citing them altogether. Montaigne, with access to the Arabic

\footnotetext{
${ }^{1}$ While Renaissance Humanism is characterized by the return to the classical sources, Modernity and Early Modernity are periods where individuals are motivated by the disruption of the traditional order. Brunold (1961) characterizes Renaissance Humanism: "Au sens historique du terme, l'humanisme fut un des aspects de ce retour aux sources antique qui, entre le XIVe et le XVIe siècles, ranima sous toutes ses formes la culture européene. Le rôle propre des humanistes dans ce grand mouvement de la Renaissance fut de mettre leur époque en pleine possession du legs des littérature anciennes” (Brunold, 1961, p. 2). Early Modernity, on the contrary, is a period of transition where, according to Koyré (1957), the "European minds underwent a deep revolution which changed the very framework and patterns of our thinking” (Koyré, 1957, p. vii). In Early Modern Europe, new worlds are being discovered, common people are developing new interpretations of sacred texts, new religious sects are underway, and citizens are demanding new forms of government and fighting for different kinds of state organizations (Park \& Daston, 2006). This was an effect of a combination of tensions that, according to Popkin (1996), were due to the intellectual crisis of the reformation and the revival of ancient skepticism. For views on Modernity as a time of radical change and rejection of tradition, see Popkin (1996), Boas (1957), Koyré (1957). An alternative interpretation will call attention for the fact that, in some places, however, tradition still reigned. The curricula of universities and the body of works used by scholarly man to learn the letters was still the same, where the classical Latin literature was among the first and most important works to be studied. Nowadays, it is common to interpret early modernity as a rich period that includes not only the iconoclasts but also thinkers that were very much engaged with tradition. For this moderate view, see the works of Pasnau (2011), Hutton (2008), and Rutherford (2006).
} 
translations of Latin and Greek texts as well as Vatican manuscripts, ${ }^{2}$ explicitly expressed his excitement with the Ancient thought by incorporating quotations of Lucretius, Ovid, Cicero, Horace, and various others in his Apology. ${ }^{3}$ Descartes, on the other hand, did not have a sense of duty towards any of these works, considering the referencing of classical authors unnecessary and even noxious. Ignoring the classics is the point de depárt or the sprit of his Discourse on Method: "sitôt que l'âge me permit de sortir de la sujétion de mes précepteurs, je quittai entièrement l'étude des lettres” (Descartes, 1987, p. 9). ${ }^{4}$ This approach is opposite of that of Montaigne who, as 16th century humanist, was an homme de lettres who valued the classical canon. ${ }^{5}$ Taking into account these two examples, we can see that the reception of Classical Latin Literature in Early Modernity is twofold: on the one hand, the learning of letters occurred through the classical literary canon influencing the style and questions raised; on the other hand, Latin language and culture represented the tradition that had to be left behind for the sake of the universalization of knowledge and freedom of thought. For this reason, the analysis of the influence of the classic Roman authors in Early Modern philosophy has to be done on a case-by-case basis

\footnotetext{
2 The work of Boutcher (2017) provides more information about Montaigne's access to books that were not available for the public.

${ }^{3}$ In the Apology of Raymond Sebond, Montaigne does direct quotation of the works of various Roman authors. The citations are so extensive in number, that they cannot be listed. Among them, the most cited authors are Cicero, Lucretius, Quintilian, Horace, Seneca, Plutarch, Pliny, Virgil, Juvenal, Martial, and Ovid. The citations are most often in the original language, so they are usually in Latin. In some cases he cites in Greek or in Italian. See Ariew \& Marjorie, 2003.

${ }^{4}$ Descartes is trying to establish firm ground for knowledge through a "general demolition" of all his opinions, which include whatever he had learned from the classical sources. In the Meditations (1641) Descartes expresses, in first person, the radical spirit of the time: "I realized that once in my life I had to raze everything to the ground and begin again from the original foundations, if I wanted to establish anything firm and lasting in the sciences” (Descartes, 2006, p. 9).

${ }^{5}$ For further analysis of Montaigne as an homme de lettres, see Brunold, 1961.
} 
given the plurality of possible perspectives on the role of the canon in the changing times. ${ }^{6}$

Spinoza's work, when interpreted against this historical background, evidences the complexity of the Early Modern reception of classical Latin authors. At first glance, Spinoza is closer to Descartes than he is to Montaigne in his treatment of the classics. In his writings, Spinoza is critical of canonical Ancient Greek philosophy: "the opinion of Plato, Aristotle, and Socrates carries little weight to me" (Ep56 to Hugo Boxel). References such as this, associated with the fact that other authors are rarely cited, give his readers reason to think that Spinoza is not, at least explicitly, interested in the classics. Further evidence can be found in the fact that Spinoza seems to agree with Descartes' principle for rational argumentation: by trying to avoid all sources of error, deductive argumentation rather than eloquence is the rightful model for philosophical investigation. Instead of appealing to classical references as an instrument of persuasion, Descartes considered them as ancillary to the systematic deduction of arguments. Instead of offering evidence, citations could take the attention of the reader from the argument at hand by an excessive appeal to imagination and the emotions of the audience. Hence, citing classical authors either as authority figures or as mere means of illustrating a commonsensical view could be deceitful. After all, the nature of citations is such that the idea conveyed comes originally from the author of the citation and, for this very reason, it does not count as an idea that had been autonomously conceived by the one who is citing. Moreover, the persuasive power of citations is directly connected with the reputation of its author, a characteristic that is disconnected from the argumentative context. For those reasons, citations count as rhetorical and literary artifice to capture the readers by their imagination. Hence, Descartes avoided direct citations, committed

\footnotetext{
${ }^{6}$ This moderate view of Early Modernity that I am entertaining in the present paper, one that interprets this time of transition as displaying a complex and multifarious relation with tradition and the classics, has also been developed by Rutherford (2007).
} 
that he was with active, and rational, knowledge. The fact that Spinoza writes Descartes' Principles of Philosophy organizing the arguments in geometrical order and composes his Ethics using the same method might be an indication that he is putting the Cartesian methodological principle to test. Although this is a good reason to think that Spinoza's philosophical method is closer to Descartes' than of Montaigne's, there is more to the story. The many layers of Spinoza's writings offer evidence for a comparison in the other direction: that Spinoza's philosophical style is, in a certain sense, closer to Montaigne's than to Descartes'.

\section{Spinoza as a Latinist}

Spinoza's writings abounds in citations of classical authors. Proietti (1985) calls him "a Hebrew who is a very sensible interpreter of non-Hebrew culture”:

Come un altro sensibilissimo interprete ebreo della cultura non ebraica, Spinoza ha talvolta accarezzato l'idea di un'opera di sole citazioni. Quanto ciò si è tradotto in scrittura, ben al di là della recommended practice seicentesca di abbellire con i classici, la pagina spinoziana ha accumulato ampie criptocitazioni e brevi frammenti di autori latini, i secondi com'è naturale, molto piú nascostamente allusivi delle prime. (Proietti, 1985, p. 210)

For Proietti, Spinoza's writings go on the opposite direction of the recommended practice of the sixteenth hundreds: instead of eliminating, Spinoza incorporates the classics. ${ }^{7}$ Proietti maps enough citations to allow us to conclude that Spinoza is in constant and uninterrupted dialogue with those works. The quoted passages found in Spinoza, however, are not as explicit as they are in Montaigne's

\footnotetext{
${ }^{7}$ Spinoza was a Latinist with evidenced interest in the classics. In his personal library, a good number of books are of classical Latin authors. Besides the GreekRoman lexicon and the Latin dictionary, on Spinoza's book inventory can be found works of Julius Caesar, Seneca, Homer, Sallust, Martial, Pliny, Virgil, Cicero, Plautus, Justinian, Euclid, Tacit, Livy, and, of course, Ovid. For the complete list, see Van Rooijen, 1889.
} 
Apology. Sometimes, when citing, Spinoza uses syntagmas such as hispano poeta (E4p39sch), illud poeta natum (E4p17sch) or simply illud poeta (E3p31cor). Those syntagmas, when they are present, help the reader to map the reference and find out its author. The "hispano poeta" is Gongora (1561-1627), and the "illud poeta" or the "illud poeta natum" is Ovid (43 BC - AD 17). However, most of the references used are indirect, constituting what Proietti calls "crypto-citations". Those references are common expressions associated with classical authors and, sometimes, full sentences quoted from their works. Since the dialogue takes the form of cryptocitations, the interchange between Spinoza and the Roman classics is easily overlooked.

Interpreters of Spinoza's Latinity such as Kajanto (1979), Akkerman (1985), and Proietti (1985) provide some kind of map of Spinoza's indirect citations. This well-established literature on classical sources in Spinoza has been limited to exploring the relationship between Spinoza and his use of the Latin language. They do not, however, investigate the argumentative context in which the citations of classic authors appear. Kajanto (1979), for example, analyses this influence in terms of Spinoza's strategy for learning of Latin. Spinoza probably started studying Latin by himself, through a text of Ovid and of Seneca (Proietti, 1985, p. 237); so it is indeed possible that the criptocitazioni were intended as a memorization strategy for learning the Latin structures and vocabulary. This pedagogical approach to the crypto-citations leads to discussions regarding the quality of Spinoza's Latin, with scholars arguing that his knowledge of the ancient language was rudimentary and not following classical syntax (Kajanto, 1979, p. 50). This discussion sometimes reduces the complexities of the issue and, although it is philologically fertile, it becomes philosophically sterile. While the work of Kajanto is focused on the grammatical structures of Spinoza's Latin and the deviations from classical Latin, Akkerman's involve the analysis of content as well as of the rhetorical structure of Spinoza's writings. For example, in a later work, Akkerman claims that the preface to the TTP follows the structure of Aristotle's Rhetorica and that the content is a continuation of the discussion 
present in Lucretius' ethics in the De rerum natura (Akkerman, 2009, p. 213). Proietti (1985), in his turn, focuses on comparing Spinoza's claims and that of the cited authors in order to demonstrate their influence. For this reason, he lists more than 70 syntagmas that are either identical or similar to those of the Latin classics. The identity or similarity is taken to be an evidence that in those syntagmas Spinoza is either citing or referring to authors such as Tacit, Lucretius, Cicero, Virgil, Horace, Ovid, Juvenal, Seneca, and Suetonius. ${ }^{8}$ Since the criptocitazioni, or crypto-citations, can only be recognized through careful attention to Spinoza's Latin and through the comparative study of his philosophy and the classical Latin literature, the extent of the philosophical influence of those authors in Spinoza's writings is left to be investigated. ${ }^{9}$

In order to find out the role that these citations play in Spinoza's arguments, they will have to be examined on their own. By taking Spinoza as a reader of ancient Roman authors and his philosophy as a locus for the study of the reception of classical ideas, the analysis of those citations in terms of their philosophical influence should shed light on Spinoza's argumentative strategies and the intricacies of Early Modern reception of classical authors. In the context of the discussions on the reception of classical literature in Early

\footnotetext{
${ }^{8}$ The central focus of Proietti's paper is to show the influence of Terence on Spinoza's Theologico-Political Treatise (TTP) and the Ethics, so he does not analyze the crypto-citations any further. Akkerman also writes on the influence of Terence on Spinoza. His own list of recognized borrowings from Terence in Spinoza's work amounts to about 150 places. Akkerman also briefly discusses borrowings of Tacitus, Seneca, Sallust, Livy, and Curius Rufus. (Akkerman, 2009, p. 211). It is possible that the list would increase if we had more research on this topic.

${ }^{9}$ Here it is important to remember the contributions of Wolfson (1943) who analyzed Spinoza's Ethics in light of the philosophy of his predecessors. However, Wolfson's major claim is that Spinoza's Ethics is a patchwork combining theses from various philosophers, which is very controversial. In the present paper, the focus of analysis is not the influence of former philosophers in Spinoza's theories, but his relationship with authors from the golden age of Latin literature, especially Ovid. It is also important to highlight the work of Wim Klever (1990; 2016) who showed the influence of Franciscus van den Enden, Spinoza's Latin professor, in his political writings.
} 
Modernity, the case of Spinoza is an example of the difficulties of investigating the presence and impact of the Roman classics in Early Modern works. To engage with this question, the next section will focus on the case of Ovid and Spinoza, and, more specifically, on the citations of Ovid that appear in the Ethics. The choice of Ovid is justified by the coincidence of topics and approaches in the works of both the philosopher and the poet, as well as by the richness of philosophical topics that this comparison can bring to light. In the next section of the paper, the analysis will focus on the citations that appear in the Ethics. The hypothesis entertained is that they evidence two perspectival similarities: metaphysical and ethical. The first two citations are evidences that Spinoza was very much interested in Ovid's descriptions of human behavior. The last two citations show that Ovid's tales of transformations find echo and inspire Spinoza's metaphysics. Finally, I will add to the analysis a fifth citation that has not been mapped by Proietti (1985) in an attempt to enlarge the list of places and topics that merit further investigation.

\section{Ovid and Spinoza: metaphysical and ethical resemblances}

There are, at least, thirteen places in Spinoza displaying either direct, indirect or crypto-citations to Ovid (Proietti, 1985, p. 256). Most citations explored by Proietti are present in Spinoza's Theologico-Political Treatise and mapped onto the verses of De Amores and the Metamorphoses. Concerning Spinoza's Ethics, Proietti finds four references to Ovid, which are the following:

(1) “meliora videre et deteriora sequi” in E3p2sch [G II 143 21-22] which appears again in E4pref [G II 205 11-12] with the difference that the verb video is conjugated in the subjunctive: "meliora sibi videat, deteriora tamen sequi". The reference is in Ov. Met. VII 20-21 where the original dictum reads as "video meliora proboque, deteriora sequor".

(2) “Unde illud poetae: Speremus pariter, pariter metuamus amantes; Ferrus est, si quis, quod sinit 
alter, amat." in E3p31cor [G II 164 23-24]. This passage is a citation from Ov. Amores II 19 (20) 4-5. Spinoza only changed the order of the original verses. In Ovid, the first verse is "Ferrus est, si quis, quod sinit alter, amat”.

(3) "qui enim veras rerum causas ignorant, omnia confundunt et sine ulla mentis repugnantia tam arbores quam homines loquentes fingunt et homines tam ex lapidibus quam ex semine formari et quascunque formas in alias quascunque mutari imaginantur.” E1p8sch2 [G II 49 31-35] - a similar sentence also appears in the TIE II 22, 21-25. Proietti sees those passages as general allusions to the Metamorphoses.

(4) "Et si sic porro in infinitum pergamus, facile concipiemus totam naturam unum esse Individuum cujus partes hoc est omnia corpora infinitis modis variant absque ulla totius Individui mutatione." E2L7sch [G II 102 12-14] - an idea that appears again in the Epistle 64 to Schuller [G IV $27828-30]^{10}$ as "facies totius Universi, quae quamvis infinitis modis variet, manet tamen semper eadem". The reference in Ovid to "facies totius" and "totius individui" is Met. XV 234.

Those crypto-citations show that in the Ethics Spinoza is in a healthy and emphatic exploration of Ovidian works and themes. The first one, translated by Curley as "we often see the better and follow the worse", appears in the context of proposition 2 of the third part of the Ethics where Spinoza is arguing that neither the body can determine the mind to think nor the mind can determine the body to act. In this proposition, Spinoza is showing that the belief that we are

\footnotetext{
${ }^{10}$ Proietti makes a mistake when citing reference 4 . Instead of pointing to the scholium of proposition 17 in the third part of the Ethics, he gives the reference to E3p19dem. The mistake is justified because he is providing the reference using Gebhardt pagination. Instead of E II 102, 11-13 which is the correct place where the expression "the whole of nature" (totam naturam) appears, he cites E II 108, 11-13. The typo can be easily sorted out because the intended expression also appears in EP 64: facies totius universi. It is also important to note that the number of this letter refers to the Gebhard Edition of the Opera Posthuma (OP), not to the De nagelate schriften (NS). Those two editions assign different numbers when indexing the correspondence.
} 
free to act and control our emotions is a false belief. We understand that this belief is false when we experience of the conflict well expressed by Ovid: we sometimes see what is better, but we follow what is worse. Spinoza further elaborates on this experience, by explaining that although we feel as if we could act according to what is best, that is, according to what we think is best, our actions are tied to our affects in such a way that we will act according to the emotions or affects that have a stronger effect in us. That is, the conflict between best and worse is not a conflict between an idea of a good action and an emotion towards a worse action, the true conflict is between two conflicting and contrary affects that are impelling us to act in these different directions. Ovid's dictum describes the exact kind of experience that Spinoza considers to be representative of the complexity and intricacies of our mind-body unity. Spinoza integrates Ov. Met. VII 20-21 to his argument because the experience described by Ovid can serve as means to improve our understanding about how and why we act. Spinoza's Ethics is an attempt to explain how our affects work, and in this effort, Ovid's dictum demonstrates a kind of experience that helps to demystify the powers of reason. Spinoza wants to show that reason does not have absolute control over the emotions. We are not "a kingdom within a kingdom" (imperium in imperio; E3pref); reason is not above human emotions, man is not above nature. The interesting point is that Ovid's dictum was only half cited. The context of the saying shows that Ovid and Spinoza are not exactly in agreement when it comes to the causes of our actions. The citation is present in his depiction of Medea's psychological struggle in this 7th book of the Metamorphoses. The tale begins with Medea pondering whether she should betray her father to help Jason or not help her love and be loyal to her father: "Ah, if I could, I should be more myself. But some strange power draws me against my will. Desire persuades me one way, reason another. I see the better and approve it, but I follow the worse." (Met VII 17-21) Medea, according to Ovid, decides to go against her reason and, following her desire, she helps Jason. There is, then, a fundamental difference between Spinoza and Ovid that the full context of the citation brings to light. While Ovid is considering that 
Medea has the ability to choose between a rational choice and an emotional choice, Spinoza is taking Ovid's reading of the case and offering an alternative explanation. According to Spinoza's understanding, Medea does not exactly have a choice: she is torn by contrary affects, and her action is a consequence of the stronger of those affects. Spinoza and Ovid do not agree with respect to the causes of our actions. However, they both share the understanding that we only relative power (potentia) over our actions. Consequently, this example shows that Spinoza singled out this citation to make it premise in his argument even though he disagrees with Ovid's conclusion in his.

The second citation (De Amores II 19/20 4-5 in E3p31cor) is another example of how Spinoza is inspired by the way Ovid sees human psychology at work. The citation comes from De amores, Ovid's personal love-elegy to a woman called Corinna. ${ }^{11}$ When Spinoza cites the verses from De Amores, the purpose is, again, to use it as premise in his argument since the citation is considered as a true account of human experience. The verses describe how human desire operates: "as lovers, let our hopes and fears be alike, insensitive is he who loves what another leaves". With this quote, Spinoza wants to show the workings of desire, sadness, and happiness: we get pleasure from imagining what others love. If we suppose that some other person loves the same person (or object) that we love, our love for this person or thing will be increased. However, following the same pattern of the former citation, Ovid is not merely being used for the sake of illustration, instead, Spinoza is thinking Ovid. The citation is part of an argument criticizing Ovid's understanding of this emotional event. Spinoza wants to claim that the endeavor to have what one loves or to be loved by everyone is

\footnotetext{
${ }^{11}$ The poem begins with an invocation of the muses as if it were the opening of an epic. However, Cupid, the protagonist and anti-hero, steals one foot from every second line of Ovid's epic, turning it into an elegiac couplet with six rhythmical units (spondees and dactyls) and one pentameter with a caesura for a strong rhythmical break. This beginning is part of a burlesque strategy to mock both the poetic genre and, through the structure of the work, set the tone of the love story. De amores narrates Ovid's fictional love affair with a married woman.
} 
ambition, not love. Ovid, instead, is claiming that lovers love and hate the same objects, describing the powers of love through the mechanisms of desire: only a man with a cold or an iron heart would not love the same object that is already loved by someone. But what Ovid calls love, Spinoza understands ambition and passive affect. The citation, in this case, is a step in the demonstration of our lower kinds of emotional experience. Spinoza cites Ovid to argue that this kind of fluctuation, although common, does not express the most genuine experience of love. The highest kind of love does not fluctuate due to external causes. It depends only on the direct relationship between the one who loves and the loved object. The degree of love will depend on the quality of the object of love and its capacity to increase and strengthen the existence of the one who loves. That is why amor intellectualis dei is, for Spinoza, the foundation for an ethical life.

The third and fourth citations concern the metaphysical themes that are common to the philosopher and the poet. In the first part of the Ethics, Spinoza argues that nature is a composite of individuals that form a single whole. Those individuals are modifications of the single substance, and, for this reason, they share common characteristics. While maintaining their singular identities, individuals are different from one another. Spinoza was aware of a potential counterargument to his defense of the existence of multiplicity as modes of a single substance. From the definition of a single substance and its identification with nature and god, a careless deduction would lead to absurd conclusions. For example, that if the substance modifies itself in an infinite number of ways, why then can stones not be transformed into human beings, men into stars or women into laurel trees? Spinoza sees in Ovid's Metamorphoses an example of what his defense of substance monism would become if taken at face value, without the constraints of laws of transformation or laws of nature. In the first part of the Ethics, Spinoza cites Ovid to illustrate what a reductio ad absurdum to his argument would lead to: 


\begin{abstract}
those who do not know the true causes of things confuse everything and without any conflict of mind feign that both trees and men speak, imagine that men are formed both from stones and from seed, and that any form whatever is changed into any other. E1p8sch2 [G II 49, 31-35]
\end{abstract}

This citation, as Curley (1985) points out in a note, is a clear reference to the theme of the Metamorphoses. Spinoza and Ovid share the interest in the changes or transformations that happen in nature. Ovid, as a poet, explores linguistically and imaginatively the extent of those changes. In the opening lines of the book 1 of the Metamorphoses, Ovid defines his theme as the mutata formas corpora $^{12}$ and asks the Gods to guide him through the words since they are responsible for all kinds of change, including the ones in language. Spinoza, in his turn, is also trying to explain how nature as well as language changes. He tries to remain close to what can be objectively described in order to describe the causes and the limits of bodily change.

Before showing how citation (4) can be similarly interpreted, I would like to add an important Ovidian syntagma reflected in Spinoza's Ethics that is left unnoticed by Proietti. There is a crucial expression used by scholars to summarize Spinoza's metaphysical views: Deus seu natura (E4pref), usually translated as "God, or Nature". This expression resembles the Ovidian verse deus et melior ... natura (Met book 1, 21), translated as "God, or a better Nature". The complete verse is "hanc deus et melior litem natura diremit", 13 translated by Brookes More as "God, or kindly Nature". The verse is in the very beginning of the Metamorphoses and marks the shift from chaos to an ordered nature. One can interpret this shift as god's intervention to create nature from chaos: "deus litem diremit”. But this does not seem to be the case because, in the beginning of the

\footnotetext{
12 "in nova fert animus mutatas dicere formas corpora" Ov. Met. I 1-2.

13 The verse is a word picture, that is, the words are arranged in a way that reinforces the meaning. The arrangement, in its turn, forms a synchysis. The words are interlocked [abab], and order established according to their case: Accusative Nominative - Accusative - Nominative.
} 
cosmogony, nature already exists: "ante mare et terras et quod tegit omnia caelum unus erat toto naturae vultus in orbe" (Met. I, lines 56). The primordial chaos in Ovid is an undifferentiated nature, a single unity appearing as whole. This lack of differentiation is then called chaos because of an incapacity of things to retain their form and distinguish themselves from the whole. The confusion of forms and things stops when nature changes itself into a greater order, that is, when god moves, providing the conditions for the differentiation of earth and sky. The result of the transformation of chaos into order is a melior natura. God does not create nature through an intervention, instead, god changes itself into something else. God is chaos and order, undifferentiated nature and ordered nature. God and nature here are one and the same thing.

The identity between god and nature in this passage on Ovid had been pointed out by McKim (1985, p. 99) in a footnote: "Ovid intends the quoted phrase to identify deus with natura, as the Stoics had."14 The identity can also be shown with a quick syntactical analysis of the verse. Although "deus et natura" is the subject of the sentence, the sintagma does not form a compound subject, because the verb diremit is singular. God and "a greater - or better kind if - nature" (melior natura) form a simple subject, indicating that Ovid considers them as a single unit. If they were different, then the verb would have been plural. Because both words perform the same function of subject, they are both in the nominative case. Since the verb is singular, the "et" in the sentence is not an additive but an alternative conjunction, playing then the same role of Spinoza's usage of "seu". The "et melior natura" of Ovid, just like Spinoza's "seu natura", works as a non-restrictive appositive. The function of an appositive

\footnotetext{
${ }^{14}$ See footnote 12 for more references in McKim, 1985. McKim also points out that Ovid's chaos is different from Hesiod's because, instead of an empty and homogeneous space, Ovid's chaos is "one of violent commotion among three distinguishable constituents - air, earth, and water - embroiled in mutual combat and in mutual transformations, constantly exchanging characteristics and even identities” (p. 99). It seems that McKim is not considering that before becoming a fight between distinguishable constituents, chaos lacked any kind of form and was totally undifferentiated. In any case, Ovid's chaos is indeed different from Hesiod's because even laking form, chaos was never empty and calm.
} 
is to allow the same thing to be said twice without repetition, which is exactly what both Ovid and Spinoza want to accomplish with the "et natura" and the "seu natura" respectively: nature is another name for God. Spinoza could also have used "deus et natura”, instead he uses seu ${ }^{15}$ given that the sintagma "deus et natura" can be translated as "god, or also, nature". Since Spinoza's intention was to stress the identity, the preferred syntagma was "deus seu natura", "god or nature".

The addition of this crypto-citation to the list of resemblances between Spinoza and Ovid is a missing piece to connect citations (1), (2), (3) with citation (4). Proietti relates citation 4 with the last book of the Metamorphoses, where Ovid reconstructs the discourse of Pythagoras. The verses that finds echo in the second part of the Ethics are the following:

nothing retains its form; but nature, the great renewer, ever makes up forms from other forms. Be sure there's nothing perishes in the whole universe; it does but vary and renew its form ... things may shift from there to here and here to there, still do all things in their sum total remain the same. (Met. XV 252-255).

Spinoza, in this case, borrowed no particular part of the verse, but made reference to this Ovidian image. There is a philosophical/thematic resemblance between the idea on those lines of the Metamorphoses and Spinoza's usage of the syntagmas "facies totius universi” in letter 64 to Schuller and in E2L7sch. Spinoza uses the expression to characterize the substance as "one Individual, whose parts, i.e. all bodies, vary in infinite ways, without any change of the whole Individual". That is, individual bodies are modifications of the single immanent substance that forms a single whole. The face

\footnotetext{
${ }^{15}$ For uses of "seu" see Caesar, Catullus, Cicero, Horatius and Ovid. When researching the particle "seu" in the Perseus database, there is a list of more than 700 classical documents where "seu" or "sive" appears. The particle appears within the following structures: "sive...sive", "seu...seu", or "seu...sive". Spinoza uses it differently from classical syntax, and instead of the longer construction sive deus sive natura or seu deus seu natura to express alternation, he opts for the simpler deus seu natura.
} 
of the whole universe is, then, in constant metamorphoses; nature varies in infinite ways, but remains always the same. Spinoza's substance and Ovid's nature are closely connected, and, after this comparative analysis, it is clear that Ovid inspired Spinoza. The resemblances shown indicate not only that Spinoza was a latinist, but also that Ovidian literature plays a strategic role in the construction of his philosophy.

\section{Crypto-citations of Ovid as a carefully crafted argumentative strategy}

As we have seen, Spinoza's usage of Ovidian images and themes through crypto-citations are much more common than what one would expect, especially when considering Descartes and Montaigne as examples. So, back to our initial questions, what does the analysis of Ovid's presence in the Ethics in the form of crypto-citations tell us about reception in Early Modernity and about Spinoza's own philosophy? With respect to reception, our conclusion could not be more general: Early Modernity is a complex period, so, reception should be studied case by case. Not only the referencing styles are varied, but also the intertextual appeal. The study of reception is important because through it the many layers of history that a philosophical work or idea carries are uncovered. ${ }^{16}$ The case of Spinoza is no different. When revisiting the influences of Spinoza in the Ethics, it is possible to sense the presence of time and experience an expansion in the texture of his text. The indirect references to Ovid, when exposed, make the text richer and more historically contextualized.

In this paper, I tried to show that the allusive intertextuality is part of Spinoza's argumentative strategy: Ovidian's ideas and images

\footnotetext{
${ }^{16}$ According to Dominguez (2000), Spinoza, in the TTP, argues that if we want to interpret any text we have to follow three steps: have a critical analysis of the history of the work, determine the meaning of the text, and determine the value judgment of the work in context. Spinoza's hermeneutical method was developed for the interpretation of sacred scriptures, nevertheless, it can be taken as a method of interpretation of any set of historical work.
} 
are taken as opinions that should be reflected upon, so they can be adequately understood. The presence of classics in Spinoza's works is not merely rhetorical; ${ }^{17}$ classical works are integrated in his arguments and their reference plays a role in the construction of his philosophy. As I have suggested in the beginning, the extensive presence of Ovid in Spinoza's writings might be surprising. The similarities between the Ethics and the Metamorphoses are, in a certain sense, controversial in light of Spinoza's criticism of imagination. For example, Hervet (2011) claims that Spinoza's view on the Metamorphoses is mainly negative:

Les Métamorphoses d'Ovide constituent un réservoir d'exemples inépuisable, mais le point de vue de Spinoza à leur égard est celui d'un rationalise qui préfère se concentrer sur les dangers de la fiction dans le domaine des science, et tourner en ridicule ces délires de l’imagination. (Hervet, 2011, p. 136)

Zourabichvili (2002) reads the presence of Ovid in Spinoza in a similar light:

La propension à “imaginer que n'importe quelles formes se changent en n'importe quelles autres” est liée à l'ignorance des choses, c'est-à-dire à leur perception mutilée: l'esprit se les représente séparément de leurs causes, dans l'incapacité où il est d'en produire la définition génétique. (Zourabichvili, 2002, p. 218-219)

Both interpreters, however, understand that although Spinoza is critical of Ovidian descriptions, using them to contrast imaginative ideas and adequate ideas from reason, those fantastic images are also being employed by Spinoza as a means to indicate the powers of language and imagination. Hervet's interpretation on the role of Ovidian images in Spinoza is that although fictions might be

\footnotetext{
${ }^{17}$ Important to note that we have been using "rhetorical" here in the same sense that Kajanto (1979) and Akkerman (1985) employed, that is, as synonym with "stylistic". Rhetoric as a discipline, however, has a broader meaning that does not exclude logic.
} 
dangerous for science, these artifacts are important for our understanding of ourselves:

La language peut faire être une chose, conférer à une chose une existence qui n'est ni intelligible ni imaginable. La chimère constitue ainsi une affirmation qui repose uniquement sur les potentialités du language et révèle à la fois notre puissance et notre impuissance. En effet, si la chimère naît de l'ignorance des cause qui déterminent une chose à exister, elle affirme également une forme de liberté. (Hervet, 2011, p. 140)

Zourabichvili arrives at the same positive conclusion:

Les Métamorphoses sont une démystification, une réduction de la chimère au statut d'ens verbale, en même temps qu'une célébration des pouvoirs du langage - puisque la métaphore nous force pour ainsi dire à imaginer l'inimaginable. (...) Ovide engendre la chimère, à la limite de l'imagination.” (Zourabichvili, 2002, p. 223)

Ovid's tales of transformations and the ideas expressed in his literary works, according to Hervet and Zourabichvili, point to the limits of imagination at the same time that it celebrates the powers of language. It seems, from their analysis and the one being entertained here, that Spinoza does not fully reject imaginative descriptions. Spinoza cites Ovid to show that when we are conscious that fictions are imaginary, those descriptions are an indication of a power of the mind. When we know that the idea in our mind is imaginative, this idea can be used for knowing our own condition and the regularities of the laws of nature. To imagine, consciously, that a tree speaks is to be reminded that trees have no voice. Imagination, when interpreted from within its power, becomes a tool for exploring the limits and essences of things. Taking these readings into account, together with the analysis of the places where the references to Ovid appear in Spinoza, we can say that Spinoza himself is using fiction as a tool for philosophical reflection. 
Throughout the paper we have seen that the citations of Ovid appear not as a form of illustration, but as means for the construction of Spinoza's theses. From what we have seen through the analysis of the crypto-citations, Spinoza is using literature as an instrument for thinking. This fact is an evidence that Spinoza is not really opposing poetic imagination and rational philosophical investigation, but is trying to show that these realms can be adequately integrated. Although Ovid's writings are all fictional, they are taken by Spinoza as meaningful descriptions of ways in which we are and live. Ovid's fictional characters carry traces of our common experiences even though they are, as imagination, a first kind of knowledge. Spinoza quotes Ovid to bring out on his reader similar traces of sensation that had been stimulated by the literary experience. But, as a philosopher, Spinoza doesn't stop there and uses those imaginative descriptions in an attempt to cause us to think about what is adequate and what is inadequate about them. Spinoza's strategy in quoting Ovid is to use the literary impressions as enablers of thought, as an affection that will have effects in the mind stimulating thought.

As a poet that writes myths, Ovid achieves verisimilitude by erasing the differences between gods and humans, between animals and plants, understanding everything that there is as things susceptible to the same process of change and transformation. It is through the contrast between what is real and what is obviously unreal that the fantastical tales become tales about the human condition. Ovid turns the imaginary into an instrument of persuasion; the images of transformation indicate an underlying commonality between all beings in nature (stones, stars, trees, and human beings, etc.). Those tales of transformation are poetically and rhetorically effective because readers, through the myths, end up experiencing the unity between different things in nature. The theme of transformation points to our common experience of recognition of our humanity in the non-human; it appeals to our experience of recognition and to our affects towards the other, towards the 
different. Ovid, in this sense, is a poet that pushes the limits of reality to, through imagination, turn the causes of the transformations explicit. For this reason, Ovid's work is an example of a constructive employment of imagination, and the fact that Spinoza cites Ovid indicates that he also considers that Ovidian fictions makes us reflect about important philosophical themes. The poet and the philosopher are an example of a successful story of the intersection between the ancient and modern classics, of literature and of philosophy, of the fantastical and the real. For this reason, the relationship between Ovid and Spinoza is philosophically rich and exciting, but the effects of this relationship to Spinoza's theory of imagination are still to be explored. The present work merely offers an invitation for further research through a small attempt of contribution to this vast topic. ${ }^{18}$

\section{Bibliography}

AKKERMAN, F. (1985). Le caractère rhétorique du "Traité théologico-politique". Spinoza entre lumiere et romantisme. Les Cahiers de Fontenay No 36-38. E.N.S. Fontenay-aux-Roses, Mars 1985. p. 381- 389.

AKKERMAN, F. (2009). Humanism and Religion in the Works of Spinoza. In: MACDONALD, A. A.; MARTELS, Z. R. W. M.; VEENSTRA, J. (edS.). Christian Humanism Essays in Honour of Arjo Vanderjagt. Leiden, Brill Online, p. 211-224.

ARIEW, R.; GRENE, M. Notes on the text. In: MONTAIGNE, M. (2003). The Apology of Raymond Sebond. Translated by Roger Ariew and Marjorie Grene. Indianapolis, Hackett publishing Company.

BOAS, G. (1957). Dominant Themes of Modern Philosophy: A History. New York, Ronald Press Co.

\footnotetext{
18 This research sponsored by a FAPESP postdoctoral fellowship registered under the project 2017/21722-5. I also thank the support of The University of São Paulo and from the Grupo de Estudos Espinosanos.
} 
BOILLAT, M. (1976). Les Métamorphoses d'Ovide Thèmes majeurs et problèmes de composition. Berne, Herbert Lang.

BOOTH, J. (1991). Ovid. The Second Book of Amores. Warminster, Aris \& Phillips.

BOUTCHER, W. (2017). The School of Montaigne in Early Modern Europe. Volume One: The Patron-Author. Oxford, Oxford University Press.

BRUNOLD, C.; JACOB, J. (1961) De Montaigne a Louis de Broglie. Paris, Librarie Belin.

CURLEY, E. (1985). The Collected Works of Spinoza. Edited and translated. Vol. 1. Princeton, Princeton University Press.

CURLEY, E. (2016). The Collected Works of Spinoza. Edited and translated. Vol. 2. Princeton, Princeton University Press.

DESCARTES, R. (1987). Discours de La Méthode. Texte et commentaire par Étienne Gilson. Paris, Vrin.

DESCARTES, R. (2006). Meditations, Objections, and Replies. Edited and Translated by Roger Ariew \& Donald Cress. Indianapolis, Hackett Publishing Company.

GALINSKI, K. (1975). Ovid's Metamorphoses. Berkeley, University of California Press.

HAZARD, P. (2013). The Crisis of the European Mind 1680-1715. Translated by J. Lewis with an Introduction by Anthony Grafton. New York, New York Review of Books. (First published in 1961).

HERVET, C. (2011). De l'imagination à l'entendement La puissance du langage chez Spinoza. Paris, Classiques Garnier.

KAJANTO, L. (1979). Aspects of Spinoza's Latinity. Arctos Acta Philologica Fennica 13, p. 49-83.

KLEVER, W. (1990). Proto-Spinoza Franciscus van den Enden. In: Studia Spinozana: An International and Interdisciplinary Series. Vol. 6, p. 281-290.

KOYRE, A. (1968). From the Closed World to the Infinite Universe. Baltimore, John Hopkins University Press. (First published in 1957). 
KRISTELLER, P. (1961). The Classic, Scholastic, and Humanistic Strains. New York, Harper \& Row Publishers.

MCKIM, R. (1985). Myth against Philosophy in Ovid's Account of Creation. The Classical Journal 80, n. 2. (Dec 1984- Jan 1985), p. 97-108.

MILLER, F. J. (1977). Ovid. Metamorphoses. Books 1-8. Loeb Classical Library. Cambridge, Harvard University Press.

MILLER, F. J. (1984). Ovid. Metamorphoses. Books 9-15. Loeb Classical Library. Cambridge, Harvard University Press.

MONTAIGNE, M. (2003). The Apology of Raymond Sebond. Translated by Roger Ariew and Marjorie Grene. Indianapolis, Hackett publishing Company.

MORE, B. (1922). Ovid. Metamorphoses. Boston, Cornhill Publishing Co.

PARK, K.; DASTON, L. (ed.) (2006). The Cambridge History of Science. Vol. 3: Early Modern Science. New York, Cambridge University Press.

POPKIN, R. (2003). The History of Scepticism: from Savonarola to Bayle. New York, Oxford University Press.

PROIETTI, O. (1985). Adulescens luxu perditus Classici Latini Nell'Opera di Spinoza. Rivista di Filosofia Neo-Scolastica 77, n. 2 (aprile-giugno 1985), p. 210-257.

RUTHERFORD, D. (2007). Innovation and Orthodoxy in Early Modern Philosophy. In: RUTHERFORD, D. (ed.). The Cambridge Companion to Early Modern Philosophy. Cambridge, Cambridge University Press, p. 11-38.

SHOECK, R. J. (1988). Intertextuality and the Rhetoric Canon. In: FEMING, R.; PAYNE, M. (ed.). Criticism, History, and Intertextuality. Toronto, Bucknell University Press, p. 98-113.

TARRANT, R. (2006). Ovid and Ancient literary history. In: HARDIE, P. The Cambridge Companion to Ovid. Cambridge, Cambridge University Press, p. 13-33.

VAN ROOIJEN, A. J. S. (1889). Inventaire des livres formant la bibliothèque de Bénédict Spinoza. La Haye, Martinus Nijhoff. 
ZOURABICHVILI, F. (2002). Spinoza Une Physique de la Pensée. Paris, PUF.

Submitted in 20/03/2017 and accepted for publication 06/10/2017

$$
\text { (c) (i) }
$$

This is an Open Access article distributed under the terms of the Creative Commons Attribution License, which permits unrestricted use, distribution, and reproduction in any medium, provided the original work is properly cited. 